\title{
Human Resource Development In Public Sector
}

\author{
Prijono Tjiptoherijanto
}

\begin{abstract}
Abstrak
Globalisasi perekonomian membawa dampak pada tuntutan efesiensi dan efektifitas dalam pengelolaan Pemerintal. Hal ini penting agar.setiap kebijakan yang keluar dari pemerintah manpu memberikan dampak yang penting terhadap perkembangan perekonomian, bukan yang sebaliknya. Kebijakan yang salah akan membarva dampak pada perekonomian karena investasi akan keluar dari Indonesia, baik domestik ataupun asing, karena batas negara yang semakin kabur:

Artikel ini menjelaskan keadaan sumberdaya manusia Indonesia sekarang dan kebijakan-kebijakan yang diambil untuk memperkuat sumberdaya manusia di sektor publik pembahasan mencakup insentif kebasis performen baik berupa pendidikan, karir dan pengupahan.
\end{abstract}

* A paper presented at the Seminar of "Quality Improvement of the Bureacracy Facing Implementation ol' Regional Autonomy" at University of Jember, Jember, East Java, Indonesia, December 6, 2000.

** Professor in Economics, University of Indonesia. 


\section{INTRODUCTION}

In the globalization era, there, are several problems that have to be faced by the Government of Indonesia. First, economic development which is indicated by high speed of information transformation and the mobility of employment and investment. The new trend will change the pattern of production, finance and trade among countries. The competitiveness in economy among countries are becoming sharper since there is no states boundaries. Second, in political aspect it is indicated by the decreasing international conflict among the countries. But, on the contrary, the regional conflict has been increasing. Furthermore, the western countries try to influence their power to other countries through economic activities. Three, the social culture interaction among countries has increased substantially and it is followed by the tendency of establishing the "international culture". The modernization of social culture will influence the economic development and technology. However, the problems will arise if the "international culture" values are so different than the national value.

In order to adapt to the situation in globalization era to the future, government has to straighten up the bureaucracy structure both in term of improving human resource condition of government employees and structuring the modern and efficient bureaucracy, Human resource development among the government officers; is expected to improve the quality of service to the community.

\section{CONDITION OF THE PUBLIC SECTOR}

The enhancement of human resource development for government employees is the right decision since the private sectors and community is still complaining about the quality of services of government employees. Even though the level of education among the government employees is quite satisfactory (around 70\% of government employees in Indonesia have a high school or more level of education and only $30 \%$ of them are junior high school or less), but the level of productivity and working performance are quite unsatisfactory. Furthermore, the distribution of employees across the institutions is still uneven. There are institutions with over employment and the other institutions have less number of employees. This uneven balance does not just occur across the institutions but also across the division within the institution. In several 
institutions or divisions the phenomenon of "under-employment" is becoming the common situation. The under-employment phenomenon can be avoided if the employee could create the job form his/herself. The creative, highly motivated and intelligent employees will not have an under-load work but on the contrary they have over-load work.

Therefore, in the future the bureaucracy system with the entrepreneurship spirit needs to be developed. Osborne and Gaebler (1993) stated that government has to focus on high quality public goods and services. Drucker (1990) stated that in order to face the changing world it is important to develop a vigorous, strong and very active government (Kartasasmita 1995). In the free trade era, the main role of government is to encourage the equal access to ail segments in the community. Furthermore, in order to bring into reality the welfare to ail Indonesian people, government employees are demanded to give priority to community rather than only to certain political party. The government employees have to guarantee the fair market competition among the economic players, which conglomerates, small businesses and cooperatives.

Regarding the role as a "community leader" there is a primary and important aspect that has to be considered by the government employee, that is "morality". Morality is not just meaning that government employees should have a good personality but also they have to avoid the irregularity and obey the rules (Magnis 1996, Natakusumah 1990). The government employee has to give priority to honesty, responsibility, integrity, and bravery. However, level of welfare, among the government employees in many cases is considered as a primary source to the lack of integrity of the employees to their duty. This is the reason why the Government, step by step, tries to improve the government employee's welfare through salary increased.

To develop the respectable community leader, government employees have to establish the image of "clean and persistent authority". Government employees are demanded to improve their services to the community through professional, competence, and honest bureaucracy. In order to run the clean and authoritative bureaucracy system, it is important to monitor and evaluate the output of personnel's work. This evaluation could be used for human resource development of government employees both for structural and functional positions. 
Evaluation for promotion has to be managed carefully based on the fairness and appropriate criteria. The criteria mean that promotion is based on the capability of personnel in such position. These criteria are used not only for promotion but also to determine the salary. The salary has to be determined by the level of responsibility and working output of personnel.

The career system of government employees has to be managed clearly and openly so every person could perceive their future career. Furthermore, employees have to understand the requirement that he or she has to have if he or she is willing to be promoted to higher position. The open and transparent career systern will reduce the subjective judgment in promotion process. Another aspect needs to be considered in order to establish the clean and authoritative government employee is a supervision process. Reinforcement including promotion and transfer have to be notified as a reward for reliable work. On the contrary, punishment should be given to the employees who could not work properly and it is hoped it will improve their performance. Indeed, the Government needs to improve the pension system for government employees so they are becoming more, secure in the retirement age.

Human resource development for government officer is started since the recruitment until the end of their service as government officer'). The selective and objective recruitment procedure and followed by integrative and systematic education, training and career system during services period is hoped to increase the quality of government employees. The Government also has to provide scholarships to get higher education both in the country and overseas for government employees who performed an extraordinary performance. This policy is not only good for the individuals but also for the institution performance in the future (World Bank 1993).

Since the First Five-year Development Plan (1968/1969 - 1973/1974) until the Sixth Five-year Development Plan (1993/1994 - 1997/1998) the Government of Indonesia has succeeded to launch laws and regulations concerning the utilization of government employee such as act No. 8/1974 concerning the government employee administration, Government Regulation No. 3/1983 concerning the Existence of State Economic Institution (Kehidupan Lembaga Perekonomian Negara), and Presidential. Decree No. 45/1974 concerning the coordination among the 
Government Institutions. However, the government employee utilization and increasing their productivity are not just as simple as formulating the laws or regulations. The issues of government employee utilization consist of three major factors which are: institution building, human resource, and administration and monitoring/controlling. The monitoring and controlling then become the main focus for the time being.

Strategies to utilize the government employee both for central and regional offices are first, establishing the development activities in ail government institutions, second, government employee performance has to be monitored and evaluated continuously; third, government employee utilization has to be implemented gradually, and fourth, the Government encourages the decentralization process (Kristiadi 1996).

\section{NUMBER AND COMPOSITION OF GOVERNMENT EMPLOYEES BY LEVEL OF EDUCATION}

Referring to article 15, Act No. 43/1999, the number and composition of government employees are decided for certain period of time based on types of job, characteristics of job and work load. Data from the National Civil Service Agency (BKN) shows that the number of government employees in 1997 is $4,094,346$ or $2.05 \%$ of total population at the same time. As stated before, the main task of government employee is to serve the community interest. Looking at the above number it means that every government employee serves around 49 people in community. Beside as a community guardianship, the government employee also has to manage the public finance as much as 35 billions US dollar. Therefore in 1997 every government employee has to manage the public finance around 8.5 thousand US dollar on average. In the future, government employee's task will be added as a motivator for community participation in national development.

For the time being, there are still many complains. from the community regarding the quality of government services. Looking at the ratio between number of government employee and population, this ratio is actually not extremely high. Therefore the Government has to take a serious consideration in expanding the level of services especially in rural and remote areas and also in improving the quality of services. 
Community's complain is not only associated with the quantity and quality but is also associated with the discipline of the employee. It is a reality that the quality, especially knowledge and skill, of government employees are still low. They are only familiar with their own job description and could not assist to solve the problems beyond their main job. Furthermore, many government employees are absent without notice during the working time. All the Above conditions should be considered by the Government seriously.

In the reality, the level of education among government employees is not so bad. The percentage of government employees with level of education more than senior high school is around $14 \%$ in 1997. Furthermore, around $60 \%$ of thern have a senior high school's level of education. Only around $16 \%$ of them are having level of education lower than high school (Table 1). Compared to the level of education of the whole employment in Indonesia, level of education of government employee is much better. In 1994, data shows that only around $15 \%$ of total employees in Indonesia graduated from high school and more (CBS 1995, Labor Force Situation in Indonesia 1994). But in fact not all jobs in government sector require the high level of education. The above situation creates a mismatch between the education background and the current job situation. In the future the issue of education will be more important since the task government employees is becoming more complex.

Gender analysis on government employee distribution shows the number of male is relatively higher than the number of female. The total ratio between male and female is around 1.8. In fact, this figure reflects the general employment situation in Indonesia. In the present time the ratio female permale labor force participation in Indonesia is around 0.58 (58 female labor force among 100 male labor force). Further analysis on Table 1 shows the ratio between male and female varies across the level of education. The paftern of ratio male per female across level of education is like "U sharp". The highest ratio male per female found in primary level of education (13.12) and it tends to decrease in line with the increasing level of education until senior high school. Above the high school level of education there is a tendency the ratio between male and female to be higher. 
Table 1

Number of Government Employee by Level of Education and Sex, 1997

\begin{tabular}{|l|r|r|r|r|r|r|r|}
\hline \multicolumn{1}{|c|}{ Education } & \multicolumn{1}{c|}{ Male } & \multicolumn{1}{c|}{$\%$} & \multicolumn{1}{c|}{ Female } & \multicolumn{1}{c|}{$\%$} & \multicolumn{1}{c|}{ Total } & \multicolumn{1}{c|}{$\%$} & \multicolumn{1}{c|}{ Ratio } \\
\hline Primary & 404,638 & 15.27 & 30,282 & 2.096 & 434,921 & 10.62 & 13,361 \\
\hline Junior High Sc. & 197,120 & 7.44 & 57,104 & 3.95 & 254,224 & 6.21 & 3,451 \\
\hline Senior High SC. & $1,423,514$ & 53.72 & $1,037,007$ & 71.79 & $2,460.521$ & 60.09 & 1.372 \\
\hline Diploma 1 & 4,056 & 0.15 & 1,782 & 0.12 & 5,838 & 0.14 & 2,276 \\
\hline Akta 1 & 20,848 & 0.79 & 22,833 & 1.58 & 43,681 & 1.07 & 0,913 \\
\hline Diploma 11 & 5,097 & 0.19 & 3,624 & 0.25 & 8,721 & 0.21 & 1,406 \\
\hline Akta 11 ${ }^{*}$ & 26,058 & 0.98 & 28,143 & 1.95 & 54,201 & 1.32 & 0,925 \\
\hline Diplorna III & 15,611 & 0.59 & 6,865 & 0.47 & 22,476 & 0.55 & 2,273 \\
\hline Akta 111 ${ }^{*}$ & 41,239 & 1.56 & 33,113 & 2.29 & 74,352 & 1.82 & 2,245 \\
\hline Academy & 140,699 & 5.31 & 69,118 & 4.78 & 209,817 & 5.12 & 2,035 \\
\hline Bachelor Degree & 362,932 & 13.69 & 152,590 & 10.56 & 515,522 & 12.59 & 2,378 \\
\hline Masters Degree & 6,382 & 0.24 & 1,624 & 0.11 & 8,006 & 0.195 & 3,929 \\
\hline Doctoral Degree & 1,816 & 0.07 & 250 & 0.02 & 2,066 & 0.05 & 7,264 \\
\hline Total & $\mathbf{2 , 6 5 0 , 0 1 0}$ & $\mathbf{1 0 0}$ & $\mathbf{1 , 4 4 4 , 3 3 6}$ & $\mathbf{1 0 0}$ & $\mathbf{4 , 0 9 4 , 3 4 6}$ & $\mathbf{1 0 0}$ & $\mathbf{1 , 8 3 4}$ \\
\hline
\end{tabular}

Note Certificate

Source BAKN, 1997

High male per female ratio in primary level ot education couid be explained by economic reason. Level of salary for government employee with low level of education is extremely low. Since the level of salary is very low it is better for them to work in other fields such as private sectors or informal sectors. Male with low level of education on the contrary intends to be a government employee since government employee has a pension system. Therefore, even though the current salary is very low, they think to be a government employee is safer for their future. Indeed most of the women with low level of education enter the informal sectors so they will have more time to take care of their family (children). Meanwhile the high ratio of male per female in higher fevel of education could be explained by looking at the differentiation opportunity between male and female to pursue higher level of education. There is a fact both in general situation and in government employees system that males have a better chance to pursue higher level of education than females. Furthermore, the number of male employees with AKTA 1 and AKTA 11 level of education - certificate which is equal to the diploma degree but it is specifically in teaching field - are slightly fewer than female employees ${ }^{2}$ (Table 1 ). 


\section{CAREER SYSTEM}

In Indonesia, government employee could be promoted into certain rank and position. Promotion in term of rank could be given based on the regular and selected promotion system (Sistem kenaikan pangkat reguler and sistem kenaikan pangkat pilihan). The regular promotion is given to employee if he/she already fulfills the certain requirements. Meanwhile the selected promotion system could be given to employee who has an extraordinary performance. Furthermore, government employee could be promoted to hold a certain position based on his/her discipline, achievement, loyalty, dedication, experience and other objective considerations. The structural position in government bureaucracy is arranged in government regulation No. 15/1994 which is renewed by a Presidential Decree No. 100/2000 and it is called echelon. There are ten level of echelons in Indonesian government bureaucracy of which the lowest is echelon $\mathrm{Vb}$ and the highest is echelon la (see: Table 2).

Table 2

Structural Position of Government Employee

\begin{tabular}{|c|c|c|c|c|c|c|c|}
\hline No. & $\begin{array}{c}\text { Echel } \\
\text { on }\end{array}$ & Beginning Position & Rank & $\begin{array}{c}\text { Continuation } \\
\text { Position }\end{array}$ & Rank & Highest Position & Rank \\
\hline 1. & la & $\begin{array}{l}\text { Pembina Utama } \\
\text { Madya }\end{array}$ & $\mathrm{IV} / \mathrm{d}$ & - & - & Pembina Utama & $\mathrm{IV} / \mathrm{e}$ \\
\hline 2. & Ib & $\begin{array}{l}\text { Pembina Utama } \\
\text { Muda }\end{array}$ & $\mathrm{IV} / \mathrm{C}$, & $\begin{array}{l}\text { Pembina } \\
\text { Utama Madya }\end{array}$ & $\mathrm{IV} / \mathrm{d}$ & Pembina Utama & $\mathrm{IV} / \mathrm{e}$ \\
\hline 3. & Ila & $\begin{array}{l}\text { Pembina Utama } \\
\text { Muda }\end{array}$ & $\mathrm{IV} / \mathrm{C}$ & - & - & $\begin{array}{l}\text { Pembina Utama } \\
\text { Madya }\end{array}$ & $\mathrm{IV} / \mathrm{d}$ \\
\hline 4. & $\mathrm{llb}$ & Pembina Tingkat I & $\mathrm{IV} / \mathrm{b}$ & $\begin{array}{l}\text { Pembina } \\
\text { Utama Muda }\end{array}$ & $\mathrm{IV} / \mathrm{C}$ & $\begin{array}{l}\text { Pembina Utama } \\
\text { Madya }\end{array}$ & $\mathrm{IV} / \mathrm{d}$ \\
\hline 5. & Illa & Pembina & $\mathrm{IV} / \mathrm{a}$ & $\begin{array}{l}\text { Pembina } \\
\text { Tingkat I }\end{array}$ & $\mathrm{IV} / \mathrm{b}$ & $\begin{array}{l}\text { Pembina Utama } \\
\text { Muda }\end{array}$ & $\mathrm{IV} / \mathrm{C}$ \\
\hline 6. & IIllb & Penata Tingkat I & $\mathrm{III} / \mathrm{d}$ & Pembina & $\mathrm{IV} / \mathrm{a}$ & Pembina Tingkat I & $\mathrm{IV} / \mathrm{b}$ \\
\hline 7. & Iva & Penata & $\mathrm{III} / \mathrm{C}$ & PenataTingkat I & $111 / \mathrm{d}$ & Pembina & $\mathrm{IV} / \mathrm{a}$ \\
\hline 8. & $\mathrm{IVb}$ & $\begin{array}{l}\text { Penata Muda } \\
\text { Tingkat I }\end{array}$ & $111 / b$ & \begin{tabular}{|l|} 
Penata \\
\end{tabular} & III/C & Penata Tingkat I & $\begin{array}{c}111 / \\
d\end{array}$ \\
\hline 9. & $\mathrm{Va}$ & Penata Muda & III/a & $\begin{array}{l}\text { Penata Muda } \\
\text { Tingkat I }\end{array}$ & $\mathrm{III} / \mathrm{b}$ & Penata & $\mathrm{III} / \mathrm{C}$ \\
\hline 10. & $\mathrm{Vb}$ & Pengatur Tingkat I & $\mathrm{II} / \mathrm{d}$ & Penata Muda & $\mathrm{III} / \mathrm{a}$ & $\begin{array}{l}\text { Penata Muda } \\
\text { Tingkat I }\end{array}$ & $\mathrm{III} / \mathrm{b}$ \\
\hline
\end{tabular}

Source: Presidential Decree No. 15/1994.

Note : In a new Govemment's Regulation No. 100/2000 there are no longer echelons Va and Vb. The lowest echelon is IV.b (Penata Muda Tingkat I) 
Among 4.09 million government employees in Indonesia, only around 268 thousand employees $(6.56 \%)$ who could achieve the echelon position during their service (Table 3). Furthermore, Table 3 shows that only $2.61 \%$ of female employees could achieve the echelon position compared to around $8.72 \%$ among males. It is also shown in the same table that ratio male per female tend to be higher as the echelon is getting higher. The highest ratio male per female occurs in echelon la where only one female among forty-two echelon la. The lowest ratio is occur in echelon $\mathrm{Vb}$ where among 5 echelon $\mathrm{Vb}$ there is one female. It is clear that males are having a better opportunity compared to female in term of achieving the echelon. The above figures do not reflect that there is a discrimination between male and female in government bureaucracy system but it rather reflects that there is a difference of quality of human resource between male and female in term of level of education.

Accordingly, Table 4 shows that in every government employee's rank the number of males are always higher than females. The highest ratio of male per female is found in rank-1 then it decreases in rank-2. After rank-2 the ratio of male per female tends to increase. These figures are actually a repetition of figures in Table 1 . It is not surprising since the rank position in government career system more or less is the output of level of education not a working performance. At the beginning of his/her services as government employee, person who is graduated from university will be given the position os "Penata Muda (III/a)" regardless his/her performances. His/her position is higher than a person who graduated from academy. Therefore in normal situation, during the whole time service as government employee, person who has better education will procure better rank in the structural position regardless his/her performance. That is why getting better education in many cases is becoming more valuable for many government employees than showing a better work performance. 
Table 3

Distribution of Government Officer's Echelon by Sex, 1997

\begin{tabular}{|l|r|l|r|r|r|r|r|}
\hline \multicolumn{1}{|c|}{ Echelon } & \multicolumn{1}{c|}{ Male } & \multicolumn{1}{l|}{ \% } & \multicolumn{1}{l|}{ Female } & \multicolumn{1}{c|}{$\%$} & \multicolumn{1}{c|}{ Total } & \multicolumn{1}{c|}{$\%$} & Ratio M/F \\
\hline Echelon I.a & 124 & 0.05 & 3 & 0.01 & 127 & 0.05 & 41.33 \\
\hline Echelon Lb & 112 & 0.05 & 8 & 0.02 & 120 & 0.04 & 14 \\
\hline Echelon ILa & 1,551 & 0.67 & 73 & 0.19 & 1,624 & 0.6 & 21.24 \\
\hline Echelon II.b & 840 & 0.36 & 22 & 0.06 & 862 & 0.32 & 38.18 \\
\hline Echelon III.a & 13,206 & 5.71 & 1,104 & 2.93 & 14,310 & 5.32 & 11.96 \\
\hline Echelon IILb & 9,277 & 4.01 & 673 & 1.79 & 9,950 & 3.7 & 13.78 \\
\hline Echelon IV.a & 52,564 & 22.7 & 7,645 & 20.3 & 60,209 & 22.4 & 6,87 \\
\hline Echelon IV.b & 37,615 & 16.3 & 5,375 & 14.3 & 42,990 & 16 & 6,99 \\
\hline Echelon V.a & 83,278 & 36 & 15,866 & 42.1 & 99,144 & 36.9 & 5,24 \\
\hline Echelon V.b & 32,548 & 14.1 & 6,910 & 18.3 & 39,458 & 14.7 & 4,71 \\
\hline TOTAL & $\mathbf{2 3 1 , 1 1 5}$ & $\mathbf{1 0 0}$ & $\mathbf{3 7 , 6 7 9}$ & $\mathbf{1 0 0}$ & $\mathbf{2 6 8 , 7 9 4}$ & $\mathbf{1 0 0}$ & $\mathbf{6 . 1 3}$ \\
\hline
\end{tabular}

Source: BAKN 1997

Table 4

Distribution of Government Officer's Rank by Sex, 1997

\begin{tabular}{|c|r|r|r|r|r|r|r|}
\hline Rank & \multicolumn{1}{c|}{ Male } & \multicolumn{1}{c|}{$\%$} & \multicolumn{1}{c|}{ Female } & \multicolumn{1}{c|}{$\%$} & \multicolumn{1}{c|}{ Total } & \multicolumn{1}{c|}{$\%$} & Ratio MIF \\
\hline I & 352.230 & 1129 & 39,961 & 2.77 & 392,191 & 9.58 & 8.81 \\
\hline II & $1,250,327$ & 47.18 & 818,891 & 56.7 & $2,069,218$ & 50.5 & 1.53 \\
\hline III & 979,073 & 36.95 & 572,1710 & 39.6 & $1,551,243$ & 37.9 & 1.71 \\
\hline IV & 68,380 & 2.58 & 13,314 & 0.92 & 81,694 & 2 & 5.14 \\
\hline Total & $\mathbf{2 , 6 5 0 , 0 1 0}$ & $\mathbf{1 0 0}$ & $\mathbf{1 , 4 4 4 , 3 3 6}$ & $\mathbf{1 0 0}$ & $\mathbf{4 , 0 9 4 , 3 4 6}$ & $\mathbf{1 0 0}$ & $\mathbf{1 , 8 3}$ \\
\hline
\end{tabular}

Source: BAKN 1997

To minimize the unfair situation regarding the educational effect on structural position, government also promotes the functional position. The functional position is developed based on certain level of knowledge and skill. The functional positions give many benefits to the employee. Competition among the employees is becoming more transparent and objective.

It is obvious that the current structural position system is becoming the long way of authority within the bureaucracy system so the efficient and effective performance can not be achieved. In the future, government intends to increase the number of functional rather than structural position 3) The structural positions such as echelon IV and echelon $V$ will be replaced by the functional position, however the echelon 1, 11, and Ill 
are still kept within the structural system. (Kompas 1996). The reason is because functional position gives a broad opportunity for government employees to enhance their capability. The number of functional positions since the First Five-Year Development Plan (Repelita 1) until the recently has increased. In the Repelita 1, there were only 8 functional positions while in budget year of $1989 / 1990$ has increased to 51 functional positions (State Ministry for Enhancing Government Employee Quality 1993).

\section{WAGES}

In order to establish a clean and authoritative government employee, the level of employee's welfare should be discussed seriously. Effectivity, productivity and quality of personnel, directly and indirectly, is related to the level of welfare such as wages or other facilities which are offered by the institution. The high level of welfare will create security and comfort in working condition and then it will affect the productivity and quality of output. It is also important to note here that high level of welfare will reduce the tendency to make a deviation in working circumstance.

The basic salary of employment in level-I (primary school and junior high school) based on the government regulation No. 15/1993 is around 10 US dollar per month or around 0.33 US dollar per day (Table 5). Meanwhile the salary for the highest level of government employee with 32 years in service is around 68.92 US dollar per month. The salary of the highest level of government employee is equivalent to the salary of teller or customer service with 2 or 3 years in service in banking company. Clearly that the level of government employee welfare is still far from satisfactory. Therefore, the best graduates from well-known universities or colleges in Indonesia are not keen to become a government employee.

As a reward for work output, wages are determined by the level of responsibility, type of job and standard of living. The wage system for government employee in Indonesia is classified as a "combination scale system" (system skala gabungan). This wage systern is a combination between single scale system and double scale system. Single scale system means that the same wage is given to employee at the same level or rank regardless of the type of job and level of responsibility. Double scale 
systern means that wages are given to employee based on the level of responsibility and type of job.

A combination scale systern means that wages for government employee are given based on the rank and then employee also receives extra allowance based on their level of responsibility and type of job. The basic salary of government employee is regulated in government regulation No. 15/1993. This basic salary is based on the period of time in service (see: Table 5). Government regulation No. 15/1993 also states that the wage of employee will be raised periodically after he/she remains in service for certain period of time and accomplishes the average performance. Beside that, employee could receive an extraordinary raise of wage is he/she has a perfect performance. There is no discrimination between male and female employee in term of deciding the basic salary. Male and female employee in term of deciding the basic salary. Male and female employee will receive the same amount if they have the same rank and length of time in service $)^{4)}$. 
Table 5

Basic Salary for Government Employee (Rupiah/Month)

\begin{tabular}{|c|c|c|c|c|c|c|c|c|c|}
\hline \multirow{3}{*}{$\begin{array}{l}\text { Length } \\
\text { in } \\
\text { service } \\
\text { (year) }\end{array}$} & \multirow{2}{*}{\multicolumn{4}{|c|}{$\begin{array}{c}\text { Rank-I } \\
\text { Basic Salary }\end{array}$}} & \multirow{3}{*}{$\begin{array}{l}\text { Length } \\
\text { in } \\
\text { service } \\
\text { (year) }\end{array}$} & \multirow{2}{*}{\multicolumn{4}{|c|}{$\begin{array}{c}\text { Rank-II } \\
\text { Basic Salary }\end{array}$}} \\
\hline & & & & & & & & & \\
\hline & \multirow{2}{*}{$\begin{array}{c}\mathbf{a} \\
78000 \\
\end{array}$} & \multirow[t]{2}{*}{ b } & \multirow[t]{2}{*}{ c } & d & & a & \multirow[t]{2}{*}{ b } & \multirow[t]{2}{*}{ c } & d \\
\hline 0 & & & & & & & & & \\
\hline 1 & & & & & & & & & \\
\hline 2 & 83600 & 92200 & 94700 & 97200 & & & & & \\
\hline 3 & & - & - & - & & & & & \\
\hline 4 & 89200 & 99000 & 102700 & 106400 & & & & & \\
\hline 5 & & - & - & 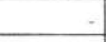 & 0 & 110100 & & & \\
\hline 6 & 94800 & 105800 & 110700 & 115600 & 1 & 117300 & & & \\
\hline 7 & - & - & - & - & 2 & - & & & \\
\hline 8 & 100400 & 112600 & 118700 & 124800 & 3 & 127300 & 129000 & 131700 & 135300 \\
\hline 9 & - & - & - & - & 4 & & - & - & - \\
\hline 10 & 106000 & 119400 & 126700 & 134000 & 5 & 137300 & 140000 & 143900 & 148700 \\
\hline 11 & & - & - & - & 6 & - & - & - & - \\
\hline 12 & 116000 & 126200 & 134700 & 143200 & 7 & 147300 & 151000 & 156000 & 162100 \\
\hline 13 & & 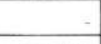 & 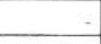 & $x^{\circ}$ & 8 & 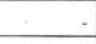 & - & - & - \\
\hline 14 & 117200 & 133000 & 142700 & 152400 & 9 & 157300 & 162000 & 168300 & 175500 \\
\hline 15 & & & $\cdot$ & - & 10 & 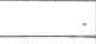 & - & - & - \\
\hline 16 & 122800 & 139800 & 150700 & 161600 & 11 & 167300 & 173000 & 180500 & 188900 \\
\hline 17 & 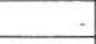 & - & - & - & 12 & 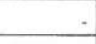 & - & - & . \\
\hline 18 & 128400 & 146600 & 158700 & 170800 & 13 & 177300 & 184000 & 192700 & 202300 \\
\hline 19 & - & - & - & - & 14 & - & - & - & - \\
\hline 20 & 134000 & 153400 & 166700 & 180000 & 15 & 187300 & 195000 & 204900 & 215700 \\
\hline 21 & - & - & - & - & 16 & ' & - & - & 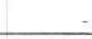 \\
\hline 22 & 139600 & $16 \cap 2 \cap 0$ & 174700 & 189200 & 17 & 197300 & 206000 & 217100 & 229100 \\
\hline 23 & - & - & - & - & 18 & - & - & - & - \\
\hline 24 & 145200 & 167000 & 182700 & $198400^{\prime}$ & 19 & 207300 & 217000 & 229300 & 242500 \\
\hline 25 & - & - & - & - & 20 & - & - & - & 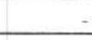 \\
\hline 26 & 150800 & 173800 & 190700 & 207600 & 21 & 217300 & 228000 & 241500 & 255900 \\
\hline \multirow[t]{12}{*}{27} & - & - & - & - & 22 & - & - & - & - \\
\hline & & & & & 23 & 227300 & 239000 & 253700 & 269300 \\
\hline & & & & & 24 & - & - & - & - \\
\hline & & & & & 25 & 237300 & 250000 & 265900 & 282700 \\
\hline & & & & & 26 & - & - & - & - \\
\hline & & & & & 27 & 247300 & 261000 & 278100 & 296100 \\
\hline & & & & & 28 & - & $\cdot \quad-$ & - & - \\
\hline & & & & & 29 & 257300 & 272000 & 290300 & 309500 \\
\hline & & & & & 30 & - & - & - & - \\
\hline & & & & & 31 & 267300 & 283000 & 302500 & 322900 \\
\hline & & & & & 32 & - & - & - & - \\
\hline & & & & & 33 & 277300 & 294000 & 314700 & 336300 \\
\hline
\end{tabular}

continued..... 
Table 5 continued.....

\begin{tabular}{|c|c|c|c|c|c|c|c|c|c|c|}
\hline \multirow{3}{*}{$\begin{array}{l}\text { Length } \\
\text { in } \\
\text { service } \\
\text { (year) }\end{array}$} & \multirow{2}{*}{\multicolumn{4}{|c|}{$\begin{array}{c}\text { Rank-III } \\
\text { Basic Salary }\end{array}$}} & \multirow{3}{*}{$\begin{array}{l}\text { Length } \\
\text { in } \\
\text { service } \\
\text { (year) }\end{array}$} & \multirow{2}{*}{\multicolumn{5}{|c|}{$\begin{array}{c}\text { Rank-IV } \\
\text { Basic Salary }\end{array}$}} \\
\hline & & & & & & & & & & \\
\hline & a & b & c & d & & a & b & c & d & e \\
\hline 0 & 150200 & 154000 & 157800 & 161600 & 0 & 168600 & 176400 & 184200 & 192000 & 201600 \\
\hline 1 & - & - & - & - & 1 & & - & - & - & - \\
\hline 2 & 164200 & 168800 & 173400 & 178000 & 2 & 186200 & 195000 & 203600 & 212200 & 222600 \\
\hline 3 & - & - & & - & 3 & & & & - & \\
\hline 4 & 178200 & 183600 & 189000 & 194400 & 4 & 203800 & 213600 & 223000 & 232400 & 243600 \\
\hline 5 & - & - & - & - & 5 & - & - & - & - & - \\
\hline 6 & 192200 & 198400 & 204600 & 210800 & 6 & 221400 & 232200 & 242400 & 252600 & 262600 \\
\hline 7 & - & - & & - & 7 & & - & - & - & - \\
\hline 8 & 206200 & 213200 & 220200 & 227200 & 8 & 239000 & 250800 & 261800 & 272800 & 285600 \\
\hline 9 & & - & - & - & 9 & - & - & - & - & - \\
\hline 10 & 220200 & 228000 & 235800 & 243600 & 10 & 256600 & 269400 & 281200 & 293000 & 306600 \\
\hline 11 & - & - & - & - & 11 & & - & - & - & - \\
\hline 12 & 234200 & 242800 & 251400 & 260000 & 12 & 274200 & 288000 & 300600 & 313200 & 327600 \\
\hline 13 & - & - & - & - & 13 & - & - & - & - & \\
\hline 14 & 248200 & 257600 & 267000 & 276400 & 14 & 291800 & 306600 & 320000 & 333400 & 348600 \\
\hline 15 & - & & - & - & 15 & - & - & - & - & \\
\hline 16 & 262200 & $2724 n 0$ & 282600 & 292800 & 16 & 309400 & 325200 & 339400 & 353600 & 369600 \\
\hline 17 & - & - & - & - & 17 & - & - & - & - & \\
\hline 18 & 276200 & 287200 & 298200 & 309200 & 18 & 327000 & 343800 & 358800 & 373800 & 390600 \\
\hline 19 & - & - & - & - & 19 & - & - & - & - & \\
\hline 20 & 290200 & 302000 & 313800 & 325600 & 20 & 344600 & 362400 & 378200 & 394000 & 411600 \\
\hline 21 & & - & - & - & 21 & - & - & - & - & \\
\hline 22 & 304200 & 316800 & 329400 & 342000 & 22 & 362200 & 381000 & 397600 & 414200 & 432600 \\
\hline 23 & - & - & - & - & 23 & - & - & - & - & - \\
\hline 24 & 318200 & 331600 & 345000 & 358400 & 24 & 379800 & 399600 & 417000 & 434400 & 453600 \\
\hline 25 & - & - & - & - & 25 & - & - & - & - & \\
\hline 26 & 332200 & 346400 & 360600 & 374800 & 26 & 397400 & 418200 & 436400 & 454600 & 474600 \\
\hline 27 & - & - & - & - & 27 & - & - & - & - & - \\
\hline 28 & 346200 & 361200 & 376200 & 391200 & 28 & 415000 & 436800 & 455800 & 474800 & 495600 \\
\hline 29 & - & - & - & - & 29 & - & - & - & - & - \\
\hline 30 & 360200 & 376000 & 391800 & 407600 & 30 & 432600 & 455400 & 475200 & 495000 & 516600 \\
\hline 31 & - & - & - & - & 31 & - & - & - & - & - \\
\hline 32 & 374200 & 390800 & 407400 & 424000 & 32 & 450200 & 474400 & 494600 & 515200 & 537600 \\
\hline
\end{tabular}

Source: Government Regulation No. 1511993 


\section{CONCLUSION}

In the future, the role of government employees will become more complex and difficult. Since the state border in term of economy, political and social culture is more vague in the free trade era, government employee is dernanded not only familiar with the domestic issues but also regional and international issues. Beside that, in the future, government employee is becoming a motivator for community participation in national development. Indeed, government employees have to guarantee the fair market competition. Consequently, the quality of government employee regardless of the sexes, needs to be improved. The selection of government employee candidates has to fulfill the requirements of capability and level of education. Selection process has to be conducted precisely. Furthermore, education and training both for preservice and in-service employees have to be given according to their demand. This education and training should be directed towards enhancement of knowledge, skill and psychological aspects. Through the improvement of bureaucracy systern and human resource development the image of clean and authoritative bureaucracy will become a reality.

\section{NOTES}

1). In the recruitment stages, job analysis and, requirement analysis should be done before the recruitment is proceeded. Furthermore, the recruitment process has been conducted fairly and openly so the government could get the best applicants as many as possible. The next step of human resource development among the government employee candidates is education and training which cover the physical, mentality and discipline aspects. The recruitment process is conducted in order to select the high capability of employee.

2). Female workers more intend to take the diploma degree in teaching field (AKTA $i$ and AKTA 11 or AKTA 111) compared to other field of study based on several reasons such as traditionally female is hoped to be an educator by community and family. Furthermore, many females have no doubt that holding the diploma in teaching field will ensure to get the job easily. On the contrary, holding the diploma in teaching field is considered as a low status of prestige by many males. 
3). Currently, several functional positions are approved by the government such as researcher and functional lecturer. Functional position as a functional lecturer is separated into 9 (nine) categories such as Asisten Widyaiswara Moda, Asisten Widyaiswara Madya, Asisten Widyaiswara, Ajun Widyaiswara Muda, Ajun Widyaiswara Madya, Ajun Widyaiswara, Widyaiswara Pratama, Widyaiswara Muda, Widyaiswara Madya, Widyaiswara Utama Pratama, Widyaiswara Utama Muda, Widyaiswara Utama Madya, and Widyaiswara Utama.

4). The fact that females' wages are less than males' wages does not necessarily mean that females face discrimination in labor markets or that they receive lower returns in labor markets to their schooling or experience. Study by Behrman and Deolalikar (1995), Goldin (1990), Berhman and Schneider (1994) indicated that female have less schooling than males in most Asian countries. They are also younger than males, which probably is associated with relatively even less work experience and training than males. Therefore the lower wage may simply reflect less schooling and less experience. Behrman and Deolalikar (1995) using the 1986 Indonesian Labor Force Survey (SAKERNAS), found the marginal increases of wage rates and earnings with post-primary schooling are greater in percentage terms for females than for males (e.g., for general senior high school, $9.1 \%$ for females and about half as much at $4.7 \%$ for males). Thus, these estimates do not suggest that females face strong discrimination in the form of lower rates of return to post-primary schooling investments, as is sometimes claimed.

\section{REFERENCES}

Behrman, J. R. and Scheneider. R. 1994. " An International Perspective on Schooling Investment in the Last Quarter Century in Some FastGrowing East and South East Asian Countries". Asian Development Review, Vo. 12, No. 2.

-, and A.B. Deolalikar, 1995. "Are There Differential Return to Schooling by Gender? The Case of Indonesian Labor Markets". Oxford Bulletin of Economics and Statistics, 57,1 (February)-. 91-118.

Central Bureau of Statistics, 1995. Social Welfare Indicators 1994. Jakarta, Indonesia. 
1995. Labor Force Situation in Indonesia 1994. Jakarta, Indonesia.

Goldin, C. 1990. Understanding the Gender Gap: An economics history of American women, Oxford University Press, New York

Kristiadi., J.B. 1996. "Policies and Bureaucracy and its impact on the legitimacy of GOLKAR Party (Kebijaksanaan dan Perilaku Birokrasi serta Pengaruhnya Terhadap Keberadaan Golongan Karya)". Paper presented at the small discussion on Penyusunan KIRKA DPP GOLKAR Tahap 1 (Formation of KIRKA DPP GOLKAR Bacth I), Jakarta, 8 April 1996.

1997. Practical Dimension of Development Management in Indonesia (Dimensi Praktis Manajemen Pembangunan di Indonesia). STIA, Jakarta, Indonesia.

Kompas, 1996 (April 17). Echelon /V and V Will be Changed to be Functional Position (Eselon IV dan V Diganti Dengan Jabatan Fungsional). Jakarta.

Kartasasmita, Ginanjar. 1.995 "The Challenge of Public Administration. Improving the service to community in Globalization Era" (Tantangan Administrasi Negara: Peningkatan pelayanan masyarakat pada Era Globalisasi). Paper presented in STIA-LAN, Batch XXIX, 21 January 1995. Jakarta.

Magnis, Suseno Frans. 1996. "Morality in Bureaucracy (Moralitas Dalam Birokrasi)". Paper presented in meeting on Efficience and Effectiveness of Bureaucratic Work Pattern and Quality of Nine Year Elementary Education in Facing Globalisation Era, Especially Toward the Year 2003 and Beyond (Effisiensi dan Effektivitas Pola Kerja Birokrasi dan Mutu Pendidikan Dasar Sembilan Tahun Dalam menghadapi Era Globalisasi, Khususnya Menyambut Tahun 2003 dan Selanjutnya). Tim-P7. Jakarta.

Natakusumah, P. 1990. Quality Improvement of Govemment Employee (Meningkatkan Kualitas Aparatur Negara). Lembaga Addministrasi Negara R.I. Jakarta, Indonesia

Prijono Tjiptoherijanto, 1993. Human Resource Development of Govemment Employee: Tentative Approach (Pengembangan 
Prijono Tjiptoherijanto

Sumber day Aparatur Pemerintah: Suatu Usulan Pengkajian). Jakarta, Indonesia.

State Ministry for Enhancing Government Employee Quality, 1993. Straighten up Govemment Employee in the Fifth Five-Year Development Plan (1988-1993). Jakarta.

World Bank, 1993. The East Asian Miracle: Economic growth and public policy. Oxford University Press.

312 